\title{
Influence of Streptomyces sp. Kp109810 on Solubilization of Inorganic Phosphate and Growth of Maize (Zea mays $\mathbf{L}$.)
}

\author{
Alaa Fathalla Mohammed \\ Agriculture Botany Dept., Faculty of Agric., Suez Canal University, Egypt
}

Received: $15 / 6 / 2020$

\begin{abstract}
Phosphorus plays a major role in plant growth, but only a small portion of phosphorus in soil is taken up by plants and the remaining part becomes unavailable for plants. Phosphate solubilizing microorganisms play a vital role in dissolving the complex form of phosphates to the accessible forms. The present paper reports the solubilization of tricalcium phosphate (TCP), single super phosphate (SSP), rock phosphate (RP), iron phosphate (FeP) and aluminum phosphate (AlP) by Streptomyces sp. KP109810 (S) with the production of organic acids as well as acid phosphatase. The amount of phosphate released $\left(562 \mathrm{mg} \mathrm{l}^{-1}\right)$ was found to be the highest in the case of single super phosphate, as compared to the other phosphate sources. The highest phosphatase activity was observed in the presence of iron phosphate (0.033 Uml-1). The proposed thin layer chromatography (TLC) method was used to analyze the organic acids in culture broths of the following P sources. The numbers of these organic acids were six organic acids from SSP, seven from RP, four organic acids from FeP and two for each of AlP and TCP. The effects of Streptomyces sp. KP109810 on P solubilization from different P sources, plant biomass production, and P content of maize (Zea mays L.) were examined in a greenhouse study. A complementary greenhouse experiment was conducted in pots by growing maize as a test crop. Our findings showed a great efficient promotion of maize growth and $\mathrm{P}$ content compared to uninoculated plants. Furthermore, single supper phosphate showed better results than rock phosphate, the latter performed comparably upon Streptomyces inoculation. These findings demonstrate that Streptomyces sp. KP109810 can improve crop growth and $\mathrm{P}$ nutrition.
\end{abstract}

Keywords: Streptomyces, TLC, Organic acids, Maize, PSB

\section{INTRODUCTION}

Phosphorus is one of the major essential plant macronutrient which plays a significant role in the development of roots, flowers and seed formation, helps in crop maturity and provides resistance to plant diseases (Khan and Jilani, 2009).

The function of certain key enzymes that are resp onsible for regulating metabolic pathways also depends on the availability of phosphorus (Tallapragada and Seshachala, 2012). Despite the high total soil P content, plant $\mathrm{P}$ availability is often reported to be limited (Collavino et al., 2010). As a result, plants can utilize 10 to $15 \%$ of the $\mathrm{P}$ added as fertilizers during a year of application (Antoun, 2012). The remaining fractions are also rapidly converted into unavailable forms in the rhizosphere around the roots, without the expected impact on agricultural yield (Fernández et al., 2012). These problems not only increase production costs, but also pollute the environment. Therefore, proper utilization of different $\mathrm{P}$ sources and improvements in their P-utilization efficiency are required to ensure sustainable food production and environmental protection across the globe.

The use of bioinoculants may be a better alternative and a complement to mineral fertilizers, since biological fertilizers could help to increase the availability of soil phosphorus, increase plant yield, minimization of harmful effects of phosphate fertilizers, reduce environmental pollution and promote sustainable agricultural development (Chen et al., 2006). In the rhizosphere, a group of soil microorganisms known as phosphate solubilizing microorganisms (PSMs) play a key role to solubilize inorganic phosphates (Illmer and Schinner, 1995; Whitelaw, 1999). PSMs are divided into two groups

*Corresponding author e-mail: Alla.Fathalla@yahoo.com (i) phosphate solubilizing bacteria (PSB) and (ii) phosphate solubilizing fungi (PSF) (Tallapragada and Seshachala, 2012). There are several previous reports about efficiency of PSBs alone or in combination with organic manures on different $\mathrm{P}$ sources for improving $\mathrm{P}$ release capacity or $\mathrm{P}$ solubilization (Harinasut et al., 2003; Fernández et al., 2007; Jain et al., 2010; Harikrishnan et al., 2014). Phosphate solubilizing bacteria (PSB), which are rhizobacteria have ability to convert complex form of phosphates to the accessible form through acidification, chelation, phosphatase enzyme and production of organic acids (Rodriguez and Fraga, 1999). Some organic acids produced by streptomycete strains were fumaric, tartaric and succinic acids (Encheva-Malinova et al., 2014). These organic acids chelate cations $(\mathrm{Al}, \mathrm{Fe}, \mathrm{Ca})$ bound to mineral phosphate forms and convert them into soluble forms available to plants through their hydroxyl and carboxyl groups (Panhwar et al., 2012). Many works recorded that the seed inoculation with PSB belonging to the genera Agrobacterium, Achromobacter, Aerobacter, Bacillus, Flavobacterium, Enterobacter, Serratia, Pseudomonas and Acinetobacter improved growth, yield and $\mathrm{P}$ uptake in several crops (Hu et al., 2010; Castagno et al., 2011; Yu et al., 2012).

The present study was undertaken to (i) establish relative potential rates of $\mathrm{P}$ solubilization of various phosphate sources by replacing tricalcium phosphate (present in Pikovskaya's medium) with rock phosphate (RP), single super phosphate (SSP), iron phosphate (FeP) and aluminum phosphate (AlP) by Streptomyces sp. KP109810. (ii) Examine the contribution of organic acids produced by Streptomyces sp. KP109810 in solubilization of phosphates. (iii) explore the role of 
Streptomyces sp. KP109810 as inoculant on maize plant growth in a greenhouse experimentof the studied traits.

\section{MATERIALS AND METHODS}

\section{Phosphate solubilization in a liquid medium:}

To determine phosphate solubilization, Streptomyces sp. KP109810 was screened on Pikovskaya's (PKV) broth medium with five different phosphate sources tricalcium phosphate (TCP), single super phosphate (SSP), rock phosphate (RP), iron phosphate (FeP) and aluminum phosphate (AlP) at initial $\mathrm{pH}$ adjusted to 7.0 and incubated at $30^{\circ} \mathrm{C}$ for 15 days in a rotary shaker at $125 \mathrm{rpm}$.. Un-inoculated flasks were served as controls. In order to remove bacterial cells and other insoluble materials, cultures were centrifuged at $10000 \mathrm{rpm}$ for $20 \mathrm{~min}$ (Liu et al., 2011). Parameters such as phosphate solublization, production of organic acid and phosphatase activity have been determined.

\section{Phosphate estimation:}

The Amount of phosphate released was determined by to Fiske-Subbarow method (Fiske and Subbarow, 1925). The supernatant $(0.5 \mathrm{ml})$ was mixed with $1 \mathrm{ml}$ of $2.5 \mathrm{M}$ sulphuric acid and $2.5 \%$ ammonium molybdate. To the above mixture $1.0 \mathrm{ml}$ of the reducing agent $(0.2 \mathrm{~g}$ of 1.0 amino-2-naphthol-4 sulfonic acid and $1.2 \mathrm{~g}$ of sodium sulfate in $100 \mathrm{ml}$ distilled water) was added. The available phosphorus was calculated at $650 \mathrm{~nm}$ by a spectrophotometer and calibrated with a standard $\mathrm{KH}_{2} \mathrm{PO}_{4}$ curve. Phosphate concentration was expressed in term of $\mathrm{mg} / \mathrm{ml}$ phosphate released in culture.

\section{Determination of organic acids by thin-layer chromatography (TLC):}

Qualitative detection of organic acids produced in the media was performed by TLC with a procedure described by Lee et al. (2001). A volume of $50 \mu \mathrm{l}$ from supernatant of Streptomyces sp. KP109810 culture and several organic acids were spotted in the bottom of silica gel plate's $0.25 \mathrm{~mm}$ silica gel plate $(20 \times 20 \mathrm{~cm}$, aluminum oxide 60 F254). Separation was performed with acetone-water-chloroform-ethanol-ammonium hydroxide $(60: 2: 6: 10: 22)$ as the solvent system. The spotted TLC plate was then placed in the bottom of the chromatographic chamber to ensure a sufficient supply of solvent vapor and the chamber was closed. The development of the chromatogram was allowed to proceed until the solvent had traveled $6-7 \mathrm{~cm}$ beyond the starting line for $20 \mathrm{~min}$ at the room temperature. Finally, the plate was dried at $120^{\circ} \mathrm{C}$ for $15 \mathrm{~min}$. The organic acids were detected by spraying an indicator solution of $0.25 \mathrm{~g}$ of methyl red and $0.25 \mathrm{~g}$ of bromophenol blue in $100 \mathrm{ml}$ of $70 \%$ methanol and the color was developed by brief heating (1-3 $\mathrm{min}$ ) in a hot dry oven $165^{\circ} \mathrm{C}$.

\section{Enzyme activity:}

Phosphatase activity was determined spectrophotometrically by using p-nitrophenyl phosphate as substrate as described by Eivazi and
Tabatabai (1977). Five hundret microlitres of the bacterial cell free culture supernatant was mixed with $1.0 \mathrm{ml}$ of pNPP solution along with $1.0 \mathrm{ml}$ of sodium acetate buffer $\mathrm{pH}$ 5.3. The reaction mixture was incubated at $40^{\circ} \mathrm{C}$ for 30 minutes. The reaction was inhibited by the addition of $2.0 \mathrm{ml}$ of $0.05 \mathrm{M} \mathrm{NaOH}$ and the absorbance was measured in triplicate at 410 $\mathrm{nm}$. The enzyme activity is defined as the amount of enzyme required to release p-nitrophenol per $\mathrm{ml}$, per minute under standard conditions.

\section{Greenhouse Experiment:}

The greenhouse experiment was conducted in the summer season 2020 at the Faculty of Agriculture, Suez Canal University, Ismailia, Egypt. This experiment was conducted to evaluate the effect of Streptomyces sp. KP109810 as bio-inoculants on maize (Zea mays L.) fertilized with different $\mathrm{P}$ sources. Six treatments were used in this investigation; control (C), Streptomyces sp. KP109810 (S+C), single super phosphate (SSP), rock phosphate (RP), S+SSP and S+RP. Inoculum of Streptomyces sp. KP109810 (S) was prepared in Luria-Bertani liquid medium at $28^{\circ} \mathrm{C}$ for $48 \mathrm{~h}$ to get $10^{8} \mathrm{CFU} \mathrm{ml}{ }^{1}$. Maize seeds (Zea Mays L.) were surface sterilized with $1.0 \%$ sodium hypochlorite solution for $5 \mathrm{~min}$, rinsed thrice in sterile distilled water and the seeds were soaked in $20 \mathrm{ml}$ of inoculum for $1.0 \mathrm{~h}$ under a gentle shaking. During the same period of time the control seeds were submerged in deionized sterilized water. The soil used in this experiment was sieved through a $2 \mathrm{~mm}$ sieve then was autoclaved and filled in plastic pots $(25 \mathrm{~cm}$ diameter and $35 \mathrm{~cm}$ depth) at the rate of $4 \mathrm{Kg} \mathrm{pot}^{-1}$. For the experimental group, $200 \mathrm{ml}$ of Streptomyces sp. KP109810 suspensions $\left(10^{8} \mathrm{CFU} / \mathrm{mL}\right)$ were mixed thoroughly with the soil for $2 \mathrm{~min}$. Non-inoculated soil served as a control. Inoculated and noninoculated seeds were planted in plastic pots $(25 \mathrm{~cm}$ diameter and $35 \mathrm{~cm}$ depth) each pot was filled with loamy sand soil. Each pot was planted with 5 seeds and then thinned to three plants after 14 days. A completely randomized design with three replications was used. Phosphorus from different sources including RP and SSP was applied at the rate equivalent to $150 \mathrm{mg} \mathrm{P} \mathrm{kg}{ }^{1}$ soil.

The data on various growth parameters including, plant dry weight $(\mathrm{g})$, plant height $(\mathrm{cm})$, stem length $(\mathrm{cm})$, root length $(\mathrm{cm})$, plant fresh weight $(\mathrm{g})$ and $\mathrm{P}$ content (mg/plant) were determined after 45 days from sowing. Plant P-content in the vegetative tissue of a plant (shoot + leaves) was determined by the vanadomolybdate phosphoric blue color method (Olsen and Sommers, 1982).

\section{Statistical Analysis:}

Preliminary data for all experiments were statistically analyzed using the appropriate analysis of variance according to (Steel, 1997) using the one way analysis of variance. A Computer program software CoStat version 6.311 was used to analysis the data of all experiments. Least significant difference (LSD) at $5 \%$ level was used separately to evaluate the response of each character in each experiment. 


\section{RESULTS AND DISCUSSION}

Phosphate solublization:

Phosphorus solubilization efficiency of Streptomyces sp. KP109810 was performed in Pikovskaya's broth supplemented with five phosphate sources TCP, SSP, RP, FeP and AlP after incubation period of 15 days. Figure (1), represents the ability of Streptomyces sp. KP109810 to dissolve insoluble phosphates for all the substrates. The results showed that the inoculation with Streptomyces sp. KP109810 has a positive effect on the five substrates. The amount of phosphate liberated reached its highest with SSP (562 $\mathrm{mg}^{-1}$ ) followed by TCP (423 $\mathrm{mg} \mathrm{l}^{-1}$ ). Rock phosphate was found to be better compared to FeP and AlP. These findings are in a good with those obtained by Hamdali et al. (2008), who found that the levels of phosphate solubilized by Streptomyces griseus and Streptomyces cavourensis were 58.9 and $83.3 \mathrm{mg} / 100$ $\mathrm{ml}$ respectively. In this respect, (Zhen Dong et al., 2013) isolated four P-solubilizing bacteria from the plant Anaphalis lacteal rhizosphere and their Pdissolving rates ranged from 65.24 to $315.36 \mathrm{mg} / \mathrm{l}$. Similar studies have been reported earlier on solubilization of TCP, RP and AlP by differrent microorganisms (Kang et al., 2002; Nath et al., 2012). The solubilization of triple super phosphate by two Bacillus spp. PSB 9 and PSB 16 was reported by Panwar et al. (2016). Son et al. (2006) isolated a Pdissolving Pantoea from the soybean rhizosphere, and soluble $\mathrm{P}$ in its culturing medium reached to $900 \mathrm{mg} / \mathrm{l}$.

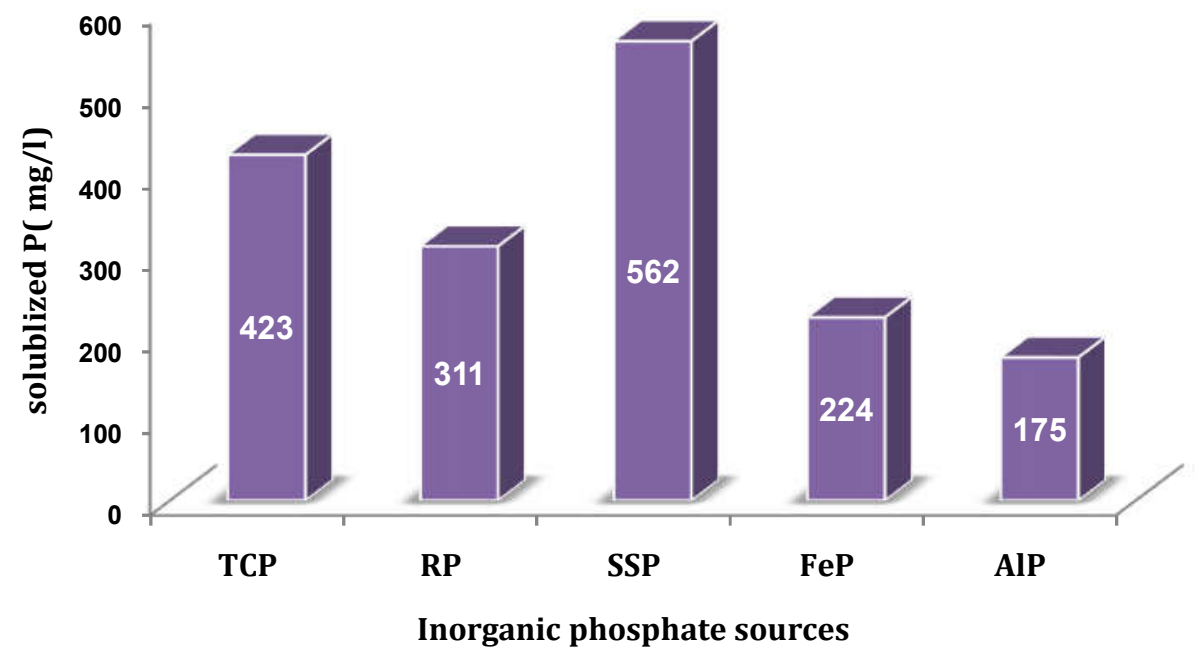

Fig (1): phosphate solublization by Streptomyces sp. KP109810 in Pikovskaya's (PVK) broth media during 15 days. Tricalcium phosphate (TCP), single super phosphate (SSP), rock phosphate (RP), iron phosphate (FeP) and aluminum phosphate (AIP)

\section{Organic acid secretion during phosphate solubilisation: \\ Detection of organic acids in the culture broth} of Streptomyces sp. KP109810 was observed through TLC during the solubilization of SSP, TCP, RP, FeP and AlP. Table (1) shows that the number and type of organic acids differed depending on the different sources of $\mathrm{P}$. Numbers of organic acids produced during the solubilization of SSP, TCP, RP, FeP and AlP were 6, 2, 7, 4 and 2 acids, respectively. The production of organic acids during phosphate solubilization is a common phenomenon, and the type of acid produced depends on the type of phosphate source (Vyas and Gulati, 2009; Mardad et al., 2013). Our findings are consistent with Vazquez et al. (2000), who also reported the production of succinic acid, lactic acid, etc. Many papers reported that major organic acids were produced by actinobacteria such as citric acid, gluconic acid, lactic acid, malic acid, and oxalic acid (Chen et al., 2006; Jog et al., 2014; Yin et al., 2017).

\section{Phosphatase activity}

Phosphatase enzymes are believed to be very important in the uptake of phosphorus by maize plants. The highest phosphatase activity was found in the media amended with RP $\left(0.091 \mathrm{Uml}^{-1}\right)$, followed by AlP (0.071 Uml $\left.{ }^{-1}\right)$, SSP $\left(0.062 \mathrm{Uml}^{-1}\right)$, TCP $(0.042$ $\mathrm{Uml}^{-1}$ ) and the lowest activity was found by $\mathrm{FeP}$ (0.033 $\mathrm{Uml}^{-1}$ ) (Fig. 2). Singh et al. (2000) stated that P. indica produced acid phosphatases to dissolve complex forms of phosphate present in rhizosphere to be more accessibility by plants. Roca et al. (2013) found that the presence of insoluble phosphate for which PSB can generate enzymes and organic acids to solubilize phosphorus was the reason behind greater alkaline phosphatase enzyme activity. 
Table (1): Detection of organic acids produced by Streptomyces sp. KP109810 and the different inorganic phosphate sources

\begin{tabular}{|c|c|c|c|c|c|}
\hline & SSP & $\mathbf{R P}$ & FeP & AIP & TCP \\
\hline \multicolumn{6}{|l|}{ Oxalic acid } \\
\hline \multicolumn{6}{|l|}{ Lactic acid } \\
\hline \multicolumn{6}{|l|}{ Citric acid } \\
\hline \multicolumn{6}{|l|}{ Succunic acid } \\
\hline \multicolumn{6}{|l|}{ Gluconic acid } \\
\hline \multicolumn{6}{|l|}{ Malic acid } \\
\hline \multicolumn{6}{|l|}{ Furmic acid } \\
\hline \multicolumn{6}{|l|}{ Acetic acid } \\
\hline \multicolumn{6}{|l|}{ Propionic acid } \\
\hline Presence (+) & & & Absence (-) & & \\
\hline
\end{tabular}

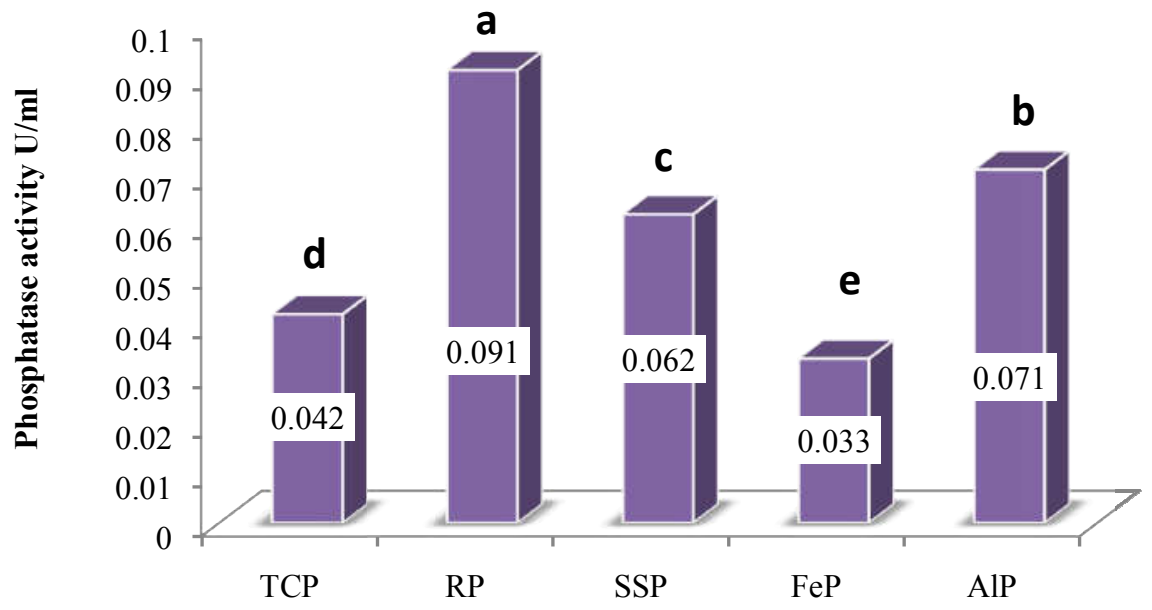

Phosphate sources

Fig (2): Effect of different phosphate sources on phosphatase activity by Streptomyces sp. KP109810. Tricalcium phosphate (TCP), single super phosphate (SSP), rock phosphate (RP), iron phosphate (FeP) and aluminum phosphate (AIP)

\section{Greenhouse experiment}

Increased plant height, plant fresh weight, shoot dry weight and root dry weight of maize plants were recorded with the plants inoculated with Streptomyces sp. KP109810. The plant height and plant weights (fresh and dry weights) were significantly $(p \leq 0.05)$ increased by the applied P fertilizers in the presence or absence of Streptomyces sp. KP109810 (Fig. 3). The total biomass (shoot and root weights) of the plants grown in soil amended with $\mathrm{S}+\mathrm{RP}$ was significantly ( $p$ $\leq 0.05$ ) greater compared to RP alone. Similarly, SSP with $\mathrm{S}$ displayed higher values compared to their sole application without S. It was observed that for most of the growth characteristics of the plants co-inoculated with S and amended with SSP displayed significantly $(p \leq 0.05)$ higher values than those supplemented with inorganic $\mathrm{P}$ fertilizer $(\mathrm{RP}+\mathrm{S})$. An increase in $\mathrm{P}$ content was observed in plants inoculated with $\mathrm{S}$. The P-uptake of maize was significantly $(p \leq 0.05)$ higher in plants treated with RP compared to those grown in the control (Fig. 4). Application of $\mathrm{S}$ with different $\mathrm{P}$ sources showed significantly $(p \leq 0.05)$ increase in plant $\mathrm{P}$ content compared to the treatments without S. It was recorded that plants treated with SSP displayed higher P-content compared to those treated with RP (Fig. 4). The P-content in plants treated with RP without $\mathrm{S}$ was $6.8 \mathrm{mg}$ plant ${ }^{1}$ that had been increased to $11.5 \mathrm{mg}$ plant ${ }^{1}$ when treated with $\mathrm{S}$. Increased growth and $\mathrm{P}$ content of several crop plants due to PSB inoculation have been reported in many studies conducted under both growth chamber and greenhouse conditions (Tao et al., 2017; Yadav et al., 2017; Danso Marfo et al., 2019). Yin et al. (2017) also reported detection of seven to eight organic acids following the application of PSBs that resulted in the solubilization of $\mathrm{P}$ and also had a positive effect on plant growth. Afzal and Bano, (2008) who reported that wheat (Triticum aestivum) inoculated with Pseudomonas sp. strain 54RB significantly increased plant height, root and shoot weight, spike length, grain and P uptake compaired the un-inoculated control. Similar results were also found in cowpea (Vigna unguiculata) which enhance the nodulation, root and shoot biomass, straw and grain yield and $\mathrm{P}$ and $\mathrm{N}$ uptake of plants inoculated with Gluconacetobacter sp. and Burkholderia sp. (Linu et al., 2009). 
A

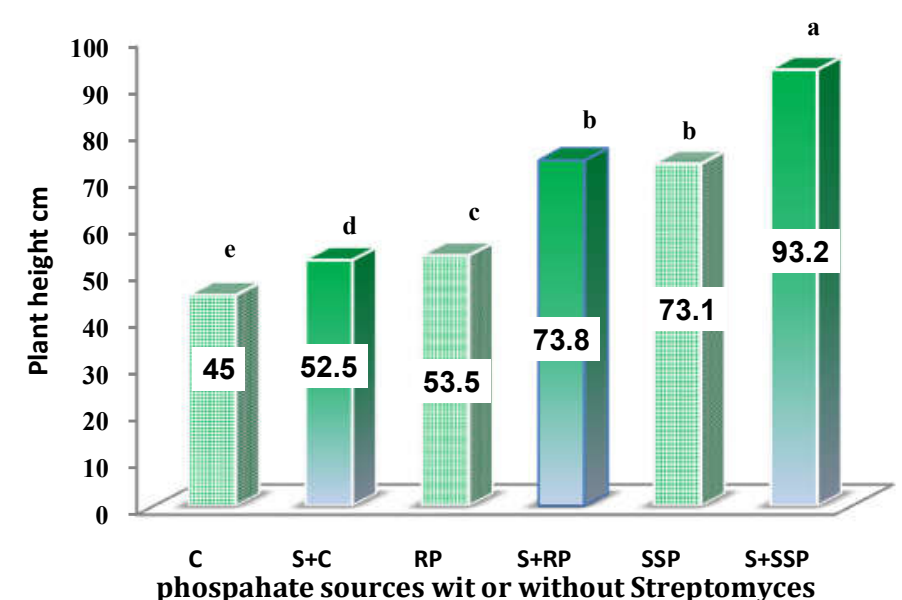

C

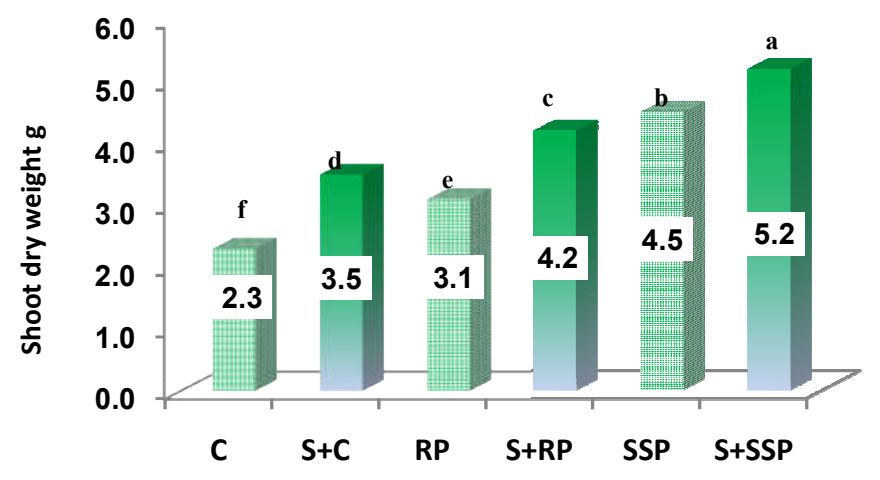

Phosphate sources with or without Streptomyces
B

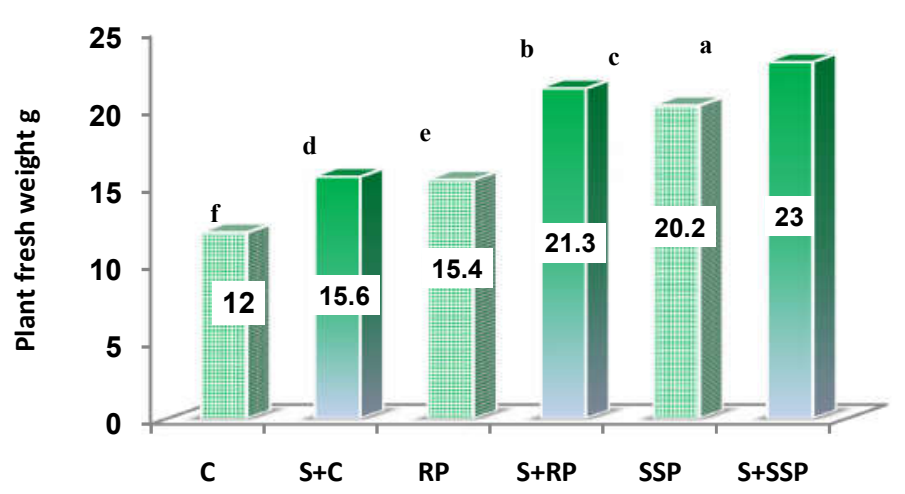

phosphate sources with or without Streptomyces

D

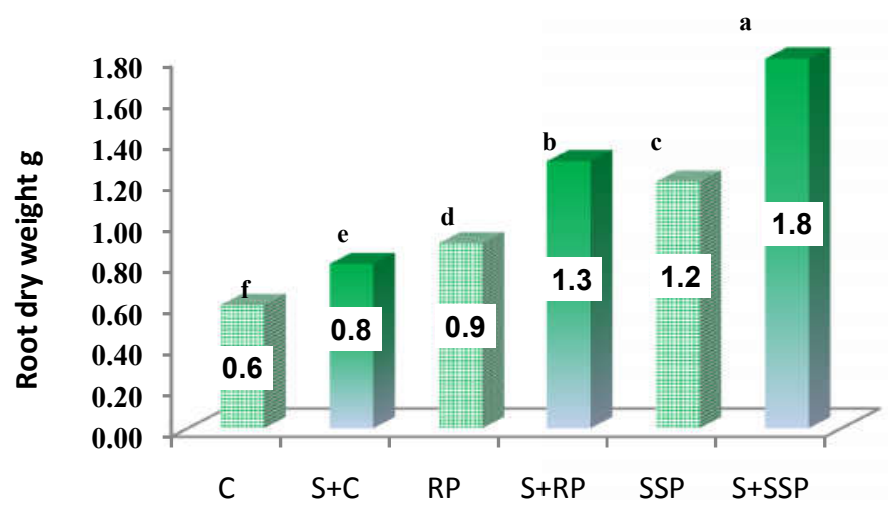

Phosphate sources with or wihout Streptomyces

Fig (3): The effect of Streptomyces sp. KP109810 (A) plant height (cm), (B) plant fresh weight (g), (C) shoot dry weight (g) and (D) root dry weight (g) of maize plants with different phosphate sources after 50 days from inoculation. Control (C), Streptomyces sp. KP109810 (S+C), single super phosphate (SSP), rock phosphate (RP) 


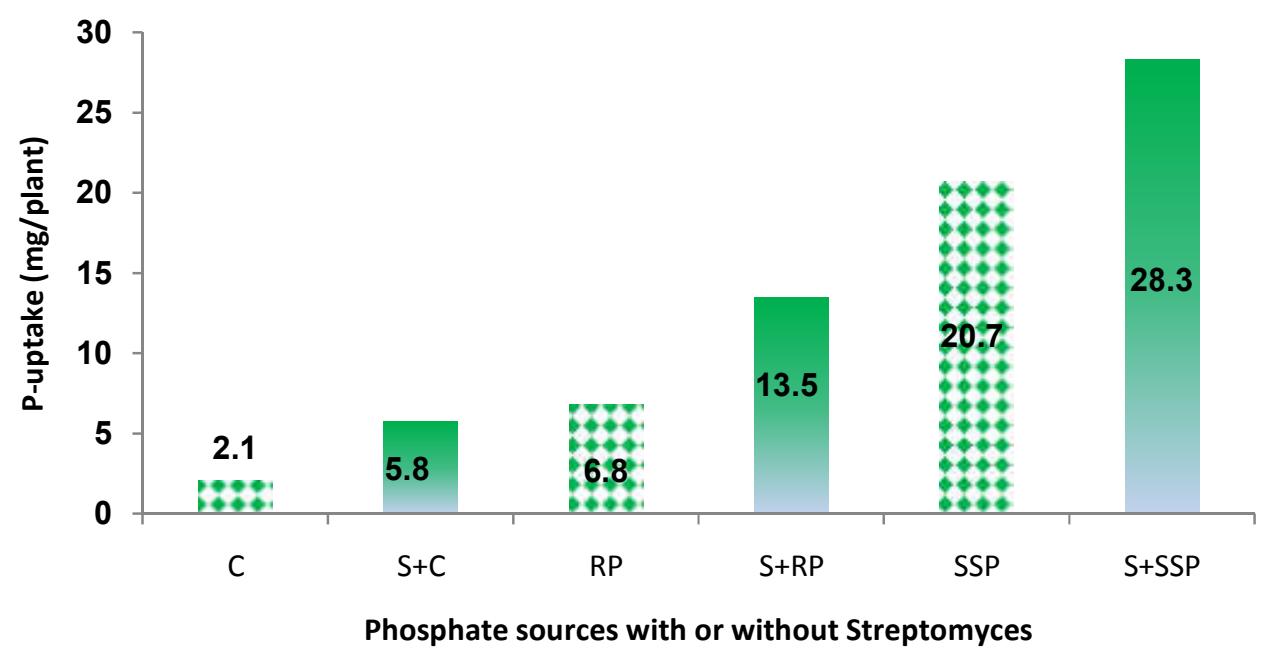

Fig (4): The effect of Streptomyces sp. KP109810 inoculation mineral P addition on P-content (mg/plant) of maize plants with different phosphate sources after 50 days from inoculation.

This investigation; control (C), Streptomyces sp. KP109810 (S+C), single super phosphate (SSP), rock phosphate (RP)

*, Different letters mean significant difference between treatments

\section{CONCLUSION}

From the results presented here, it is reported the solubilization of five different inorganic phosphate sources namely TCP, RP, SSP, FeP and AlP by the actinobacterial strain Streptomyces sp. KP109810 differed significantly depending on the nature of phosphate source. Many organic acids present in the medium were detected by TLC and the organic acids production differed according to the different sources of P. Phosphatase activity was reported in Streptomyces sp. KP109810 with a maximum activity of $0.091 \mathrm{Uml}^{-1}$ by RP sample. Our results suggest that Streptomyces sp. KP109810 were effective in solubilization of RP, thus, improving its capacity to release $\mathrm{P}$ for cultivated plants. The application of this actinobacterial strain had beneficial effects on growth, yield and $\mathrm{P}$ nutrition on maize plants. These results have an agronomic importance for crop cultivation, economic importance for saving money involved in high cost chemical $\mathrm{P}$ fertilizers, and environmental benefits for avoiding environmental issues caused due to mineral $\mathrm{P}$ fertilizer application. Hence, application of $\mathrm{P}$ solubilizing bacteria are recommended as a sustainable way for increasing $\mathrm{P}$ solubilization from insoluble RP and other P sources, and improving crop yield and $\mathrm{P}$ utilization efficiency of applied $\mathrm{P}$ fertilizers. These results are recommended to be evaluated under various soils and environmental conditions before using this actinobacterial strain as a biofertilizer.

\section{REFERENCES}

Afzal, A. and A. Bano (2008). Rhizobium and Phosphate Solubilizing Bacteria Improve the Yield and Phosphorus Uptake in Wheat (Triticum aestivum), Int. J. Agri. Biol., 10: 1560-8530.
Antoun, H. (2012). Beneficial Microorganisms for the Sustainable Use of Phosphates in Agriculture, Procedia Engineering, 46: 62-67.

Castagno, L., M. Estrella, A. Sannazzaro, A. Grassano, and O. Ruiz (2011). Phosphate-solubilization mechanism andin vitroplant growth promotion activity mediated by Pantoea eucalypti isolated from Lotus tenuis rhizosphere in the Salado River Basin (Argentina), Journal of Applied Microbiology, 110 (5): 1151-1165. doi: 10.1111/j.1365-2672.2011.04968.x.

Chen, Y. P., P. D. Rekha, A. B. Arun, F. T. Shen, W.A. Lai, and C. C. Young (2006). Phosphate solubilizing bacteria from subtropical soil and their tricalcium phosphate solubilizing abilities, Applied Soil Ecology, 34(1): 33-41. doi: 10.1016/j.apsoil.2005.12.002.

Collavino, M. M., P. A. Sansberro, L. A. Mroginski, and O. M. Aguilar (2010). Comparison of in vitro solubilization activity of diverse phosphate-solubilizing bacteria native to acid soil and their ability to promote Phaseolus vulgaris growth, Biology and fertility of soils, 46(7): 727-738

Danso Marfo, T., R. Datta, V. Vranová, and A. Ekielski (2019). Ecotone Dynamics and Stability from Soil Perspective: ForestAgriculture Land Transition.

Eivazi, F. and M. A. Tabatabai (1977). Phosphatases in soils, Soil Biology and Biochemistry, 9(3): $167-$ 172, doi: 10.1016/0038-0717(77)90070-0.

Encheva-Malinova, M., M. Stoyanova, H. Avramova, Y. Pavlova, B. Gocheva, I. Ivanova, and P. Moncheva (2014). Antibacterial potential of streptomycete strains from Antarctic soils, Biotechnology \& Biotechnological Equipment, 28(4): 721-727. doi: $10.1080 / 13102818.2014 .947066$. 
Fernández, L., B. Agaras, P. Zalba, L. G. Wall and C. Valverde (2012). Pseudomonas spp. isolates with high phosphate-mobilizing potential and root colonization properties from agricultural bulk soils under no-till management, Biology and fertility of soils, 48(7): 763-773.

Fernández, L. A., P. Zalba, M. A. Gómez and M. A. Sagardoy (2007). Phosphate-solubilization activity of bacterial strains in soil and their effect on soybean growth under greenhouse conditions, Biol Fertil Soils, 43(6): 805-809, doi: 10.1007/s00374-007-0172-3.

Fiske, C. H. and Y. Subbarow (1925). The Colorimetric Determination of Phosphorus, J. Biol. Chem., 66(2): 375-400.

Hamdali, H., B. Bouizgarne, M. Hafidi, A. Lebrihi, M. J. Virolle and Y. Ouhdouch (2008). Screening for rock phosphate solubilizing Actinomycetes from Moroccan phosphate mines, Applied Soil Ecology, 38(1): 12-19. doi: 10.1016/j.apsoil.2007.08.007.

Harikrishnan, H., V. Shanmugaiah, N. Balasubramanian, M. P. Sharma and S. O. Kotchoni (2014). Antagonistic potential of native strain Streptomyces aurantiogriseus VSMGT1014 against sheath blight of rice disease, World J Microbiol Biotechnol, 30(12): 3149-3161, doi: 10.1007/s11274-0141742-9.

Harinasut, P., D. Poonsopa, K. Roengmongkol and R. Charoensataporn (2003). Salinity effects on antioxidant enzymes in mulberry cultivar, Science Asia, 29(2): 109-113.

Hu, X.-J., Z.-J. Li, Y.-C. Cao, J. Zhang, Y.-X. Gong and Y.-F. Yang (2010). Isolation and identification of a phosphate-solubilizing bacterium Pantoea stewartii subsp. stewartii g6, and effects of temperature, salinity, and $\mathrm{pH}$ on its growth under indoor culture conditions, Aquaculture International, 6(18): 1079-1091, doi: 10.1007/s10499-010-9325-8.

Illmer, P. and F. Schinner (1995). Solubilization of inorganic calcium phosphates-Solubilization mechanisms, Soil Biology and Biochemistry, 27(3): 257-263. doi: 10.1016/00380717(94)00190-C.

Jain, R., J. Saxena and V. Sharma (2010). The evaluation of free and encapsulated Aspergillus awamori for phosphate solubilization in fermentation and soil-plant system, Applied Soil Ecology, 46(1): 90-94. doi: 10.1016/j.apsoil.2010.06.008.

Jog, R., M. Pandya, G. Nareshkumar and S. Rajkumar (2014). Mechanism of phosphate solubilization and antifungal activity of Streptomyces spp. isolated from wheat roots and rhizosphere and their application in improving plant growth, Microbiology (Reading, England), 160(Pt 4): 778-788. doi: 10.1099/mic.0.074146-0.

Kang, S. C., C. G. Ha, T. G. Lee and D. K. Maheshwari (2002). Solubilization of insoluble inorganic phosphates by a soil-inhabiting fungus Fomitopsis sp. PS 102, Current Science, 82(4): 439-442.

Khan, A. and G. Jilani (2009). Phosphorus solubilizing bacteria: occurrence, mechanisms and their role in crop production. Agric. Biol. Sci., 1(1): 4858.

Lee, K. -Y., J. -S. So and T. -R. Heo (2001). Thin layer chromatographic determination of organic acids for rapid identification of bifidobacteria at genus level, Journal of Microbiological Methods, 45(1): 1-6. doi: 10.1016/S01677012(01)00214-7.

Linu, M. S., J. Stephen and M. S. Jisha (2009). Phosphate solubilizing Gluconacetobacter sp., Burkholderia sp. and their potential interaction with cowpea (Vigna unguiculata (L.) Walp.)., International Journal of Agricultural Research, 4(2): 79-87.

Liu, H., X.-Q. Wu, J.-H. Ren and J.-R. Ye (2011). Isolation and Identification of Phosphobacteria in Poplar Rhizosphere from Different Regions of China, Pedosphere, 1(21): 90-97. doi: 10.1016/S1002-0160(10)60083-5.

Mardad, I., A. Serrano and A. Soukri (2013). Solubilization of inorganic phosphate and production of organic acids by bacteria isolated from a Moroccan mineral phosphate deposit., African Journal of Microbiology Research, 7(8): 626-635.

Nath, R., G. D. Sharma and M. Barooah (2012). Efficiency of Tricalcium Phosphate Solubilization by Two Different Endophytic Penicillium sp. Isolated from Tea (Camellia sinensis L.)., Eur. J. Exp. Biol., 2(4): 13541358.

Olsen, S. R. and L. E. Sommers (1982). Phosphorus in AL Page, (Ed). Methods of Soil Analysis. Part 2. Chemical and Microbiological Properties. Agronomy Mongraphs, 9(2).

Panhwar, Q. A., R. Othman, Z. A. Rahman, S. Meon and M. R. Ismail (2012). Isolation and characterization of phosphate-solubilizing bacteria from aerobic rice., African Journal of Biotechnology, 11(11): 2711-2719.

Panwar, M., R. Tewari and H. Nayyar (2016). Native halo-tolerant plant growth promoting rhizobacteria Enterococcus and Pantoea sp. improve seed yield of Mungbean (Vigna radiata L.) under soil salinity by reducing sodium uptake and stress injury, Physiol. Mol. Biol. Plants, 22(4): 445-459, doi: 10.1007/s12298016-0376-9.

Roca, A., P. Pizarro-Tobías, Z. Udaondo, M. Fernández, M. Matilla, A. Molina-Henares, L. Molina, A. Segura, E. Duque and J.-L. Ramos (2013). Analysis of the plant growth-promoting properties encoded by the genome of the rhizobacterium Pseudomonas putida BIRD-1, Environmental Microbiology, 15(3): 780-794, doi: 10.1111/1462-2920.12037.

Rodriguez, H. and R. Fraga (1999). Phosphate solubilizing bacteria and their role in plant 
growth promotion, Biotechnol., 17(4-5): 319339.

Singh, A., J. Sharma, K.-H. Rexer and A. Varma (2000). Plant productivity determinants beyond minerals, water and light: Piriformospora indica - A revolutionary plant growth promoting fungus, Current Science, 79(11): 1548-1554.

Son, H. -J., G. -T. Park, M. -S. Cha, and M. -S. Heo (2006). Solubilization of insoluble inorganic phosphates by a novel salt- and $\mathrm{pH}$-tolerant Pantoea agglomerans R-42 isolated from soybean rhizosphere, Bioresource Technology, 97(2): 204-210. doi: 10.1016/j.biortech.2005.02.021

Steel, R. G. (1997). Pinciples and procedures of statistics a biometrical approach.

Tallapragada, P. and U. Seshachala (2012). Phosphatesolubilizing microbes and their occurrence in the rhizospheres of Piper betel in Karnataka, India., Turkish Journal of Biology. 36(1).

Tao, J., X. Liu, Y. Liang, J. Niu, Y. Xiao, Y. Gu, L. Ma, D. Meng, Y. Zhang, W. Huang, et al. (2017). Maize growth responses to soil microbes and soil properties after fertilization with different green manures. Applied Microbiology and Biotechnology, 101(3): 12891299.

Vazquez, P., G. Holguin, M. E. Puente, Lopez-Cortes A. and Y. Bashan (2000). Phosphatesolubilizing microorganisms associated with the rhizosphere of mangroves in a semiarid coastal lagoon, Biology and Fertility of Soils, 30(5-6).

Vyas, P. and A. Gulati (2009). Organic acid production in vitro and plant growth promotion in maize under controlled environment by phosphate- solubilizing fluorescent Pseudomonas, BMC Microbiol. 9(1): 174. doi: 10.1186/1471-21809-174.

Whitelaw, M. A. (1999). Growth Promotion of Plants Inoculated with Phosphate-Solubilizing Fungi, in Advances in Agronomy D. L. Sparks (Editor), Academic Press, 99-151, doi: 10.1016/S0065-2113(08)60948-7.

Yadav, A. N., Dr. P. Verma, B. Singh, V. Chauhan, A. Suman and A. Saxena (2017). Plant Growth Promoting Bacteria: Biodiversity and Multifunctional Attributes for Sustainable Agriculture, Advance in Biotechnology and Microbiology, 5(1-16). doi: 10.19080/AIBM.2017.05.555671.

Yin, Z., B. Fan, D. P. Roberts, S. Chen, F. Shi, J. S. Buyer and H. Jiang (2017). Enhancement of maize growth and alteration of the rhizosphere microbial community by phosphate-solubilizing fungus Aspergillus aculeatus P93, 01, Journal of Agriculture Biotechnology, 2(01).

Yu, X., X. Liu, T. -H. Zhu, G. -H. Liu and C. Mao (2012). Co-inoculation with phosphatesolubilzing and nitrogen-fixing bacteria on solubilization of rock phosphate and their effect on growth promotion and nutrient uptake by walnut, European Journal of Soil Biology Complete, 50: 112-117. doi: 10.1016/j.ejsobi.2012.01.004.

Zhen Dong, L., C. XiuRong, Y. ChengDe and L. Peng (2013). Screening, identification and solubilizing properties of the endophytic phosphate-solubilizing bacteria isolated from Anaphalis lactea., Acta Prataculturae Sinica, 22(6): 150-158.

\section{تأثير ميكروب Streptomyces sp. KP109810 على إذابة القوسفات غير العضوي ونمو الذرة (Zea mays L.)

\author{
آلاء فتح الله محمد فرج سعيد \\ قسم النبات الزر اعي ـ كلية الزراعة ـ جامعة قناة السويس ـ الإسماعيلية ـ مصر
}

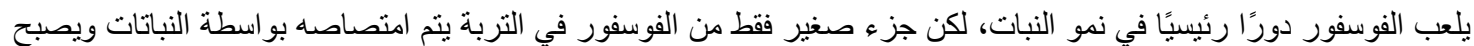

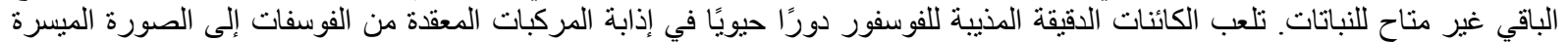

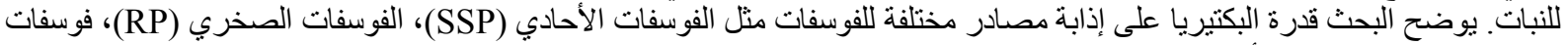

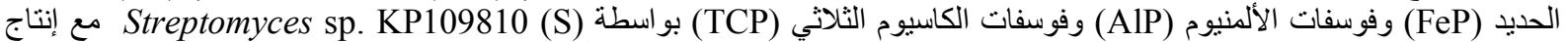

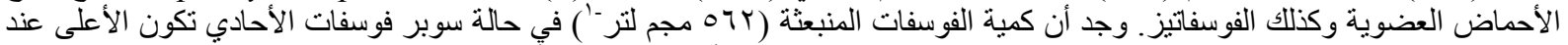

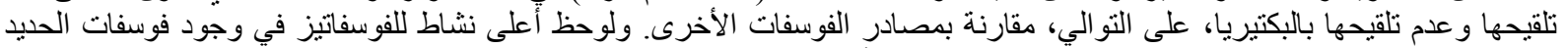



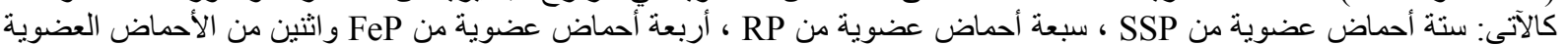

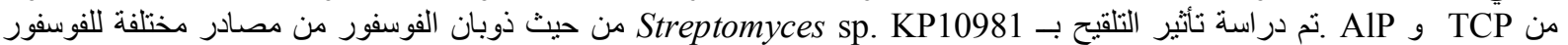

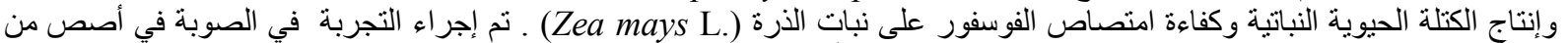

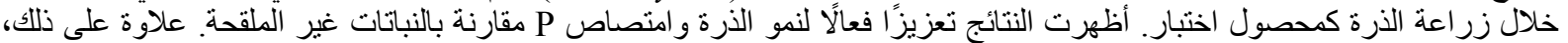

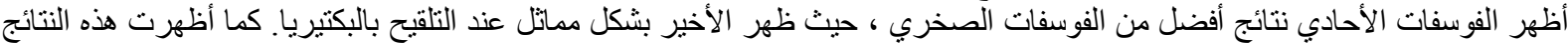

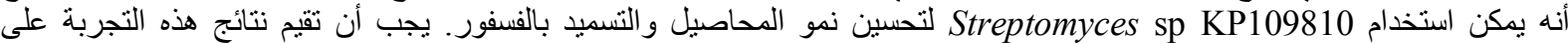
المستوى الحقلي تحت ظروف أر اضى وبيئات مختلفة قبل التوصية باستخدام هذه السلالة الميكروبية كسماد حيوي. 